\title{
Efficient Exploitation of Beech Wood by Production of an Atypical Structural Element - a Hollow Wooden Post
}

\section{Učinkovito iskorištavanje bukovine proizvodnjom netipičnoga konstrukcijskog elementa - šupljega drvenog stupa}

Preliminary paper • Prethodno priopćenje

Received-prispjelo: 19. 1. 2017.

Accepted-prihvaćeno: 30. 8. 2017.

UDK: $630 * 831.5 ; 674.031 .632 .224 .2$

doi:10.5552/drind.2017.1703

\begin{abstract}
The aim of the article is to quantify the financial cost of an atypical structural element - a hollow wooden post, and thus determine its market price. This price is subsequently compared to the prices of materials offered by the current market. The calculation of costs is generally defined as balancing costs, profits, and other variables per a labour unit producing the item. A hollow wooden post is a multi-functional construction member. A complex of physical, mechanical, operational and aesthetic properties makes it suitable for use indoors and outdoors, in combination with other materials, as well as for load-bearing and aesthetic purposes. The production of composite materials enhances efficient exploitation of wood raw material. Current advanced technologies not only allow to process less valuable wood assortments, but also wood waste materials from mechanical processing. Thus, the price depends primarily on the input material used, production technology, construction and final design with respect to the purpose of a product. The price of wood raw material is relatively low compared to that of other developed countries. However, the price of engineered wood is high. The price of solid structural timber (KVH) is around $€ 450.00 / \mathrm{m}^{3}$. In case of glued wood DUO, TRIO, the market price is $€ 650.00 / \mathrm{m}^{3}$. The cost of $1 \mathrm{~m}^{3}$ of laminated veneer lumber (LVL) of various materials is around $€ 1,850.00 / \mathrm{m}^{3}$. Thus, the price of wood materials with higher added value is considerably higher compared to materials from solid wood in the form of timber used for structural members. In case of hollow beech posts, as structural glued materials with added value, the calculated price is $€ 2,175.00 / \mathrm{m}^{3}$.
\end{abstract}

Keywords: hollow wooden post, beech wood, construction member, price of the product

SAŽETAK • Cilj rada bio je kvantificirati troškove proizvodnje netipičnoga konstrukcijskog elementa - šupljega drvenog stupa, i utvrditi njegovu tržišnu cijenu. Ta je cijena zatim uspoređena s cijenama konstrukcijskih materijala koji se nude na tržištu. Troškovi proizvodnje općenito se definiraju kao troškovi uravnoteženja, dobiti i drugih varijabli izraženi po jedinici rada za proizvodnju određenog proizvoda. Šuplji drveni stup multifunkcionalni je građevni element. Skup fizičkih, mehaničkih, operativnih i estetskih svojstava čine ga pogodnim za uporabu u zatvorenome i vanjskom prostoru, u kombinaciji s drugim materijalima, a služi kao nosivi ili estetski element. Pritom

\footnotetext{
${ }^{1}$ Authors are associate professor and PhD student at the Faculty of Wood Science and Technology, Technical University in Zvolen, Slovakia. ${ }^{1}$ Autori su izvanredni profesor i doktorandica Fakulteta znanosti o drvu i drvne tehnologije, Tehničko sveučilište u Zvolenu, Republika Slovačka.
} 
valja napomenuti da današnja proizvodnja kompozitnih materijala povećava učinkovitost iskorištenja drvne sirovine. Naime, napredne tehnologije ne omogućuju samo obradu manje vrijednih drvnih sortimenata nego i drvnih ostataka nastalih pri mehanickoj obradi drva. Dakle, cijena proizvoda ponajprije ovisi o upotrijebljenome ulaznom materijalu, zatim o tehnologiji proizvodnje, konstrukciji i završnom dizajnu proizvoda s obzirom na njegovu namjenu. Cijena drvne sirovine u Slovačkoj relativno je niska u usporedbi s cijenama sirovine u ostalim razvijenim zemljama, no cijena drvnih građevnih materijala visoka je. Cijena masivnoga konstrukcijskog drva (KVH) iznosi oko 450 eura $/ \mathrm{m}^{3}$, a tržišna je cijena lijepljenoga drvnog materijala (DUO, TRIO) 650 eura/m³. Jedan kubni metar lameliranog drva (LVL) od različitog materijala košta oko 1.850 eura. Dakle, cijena drvnog materijala veće dodane vrijednosti znatno je veća u usporedbi s cijenom konstrukcijskog materijala od masivnog drva. Za šuplji bukov stup kao konstrukcijski element izrađen od lijepljenih drvenih elemenata izračunana je cijena koštanja od 2175 eura/m . $^{3}$

Ključne riječi: šuplji drveni stup, bukovina, konstrukcijski element, cijena proizvoda

\section{INTRODUCTION}

\section{UVOD}

Nowadays, approximately 500,000 $\mathrm{m}^{3}$ of hardwood logs is processed in Slovakia. The finest wood assortments of exceptional quality are processed on a small scale and wood products with high added value are largely deficient (Zelená správa, 2015). Beech wood, the most prevalent wood species in Slovakia, possesses many physical, mechanical and technological qualities, and it is our most important leafy raw wood material used for industrial processing (Klement and Huráková, 2016). In the past, it was used predominantly as firewood, but also as the main material in the production of charcoal.

More industrial exploitation of beech wood by mechanical means initiated the manufacture of bentwood chairs and furniture, which furthered industrial production of molded plywood (Igaz et al., 2016). Gradually, the production of beech timber was launched (Krišták et al., 2014). To date, it has been processed primarily to satisfy the needs of the furniture industry. Beech dimension timber is used to make bent-seating furniture as well as cut furniture, and as construction frames for upholstered furniture. Another significant product is glued wood for various interior elements such as staircases, furniture, flooring and the like. Beech wood is also processed into railway sleepers, whose production took off especially after the World War II. Beech wood is also used for manufacturing of special products such as toys, sports equipment and accessories.

The processing methods are, however, societydriven, and therefore some of the products are on the increase, while others are on the decline. It is essential, though, to investigate new methods of exploitation of the material, especially with respect to efficiency (Kúdela and Čunderlík, 2012; Klement and Huráková, 2015). Recent years have seen rising demand for sawmill products containing false heartwood. The reason was to create unique products, which, however, are not accepted in commercial products (Prekrat et al., 2004). It should be noted that the presence of false heartwood would be tolerated in case of lower quality timber (Popadič et al., 2014).

A wooden post is recognised as one of the essential construction components. With regard to an efficient use of raw wood material, a hollow wooden post was de- signed as an alternative to a solid wooden post. A hollow wooden post has a relatively wide range of applications in wooden constructions (Detvaj et al., 2008). From the construction point of view, it is an element, which is made by gluing of twelve pieces of trapezoid-cut staves (Holý and Detvaj, 2011). Such a solution saves 13-15\% of material compared to solid wood posts of the same load-bearing capacity. There are various construction designs of a hollow wooden post. The design depends mainly on the currently available technology, purpose and place of its use. Ultimately, the price is a critical factor determining how and for whom to produce. In general terms, the price of goods and services stems from the development of demand and offer of goods and services on the market (Janok and Oláh, 1996).

\section{MATERIALS AND METHODS 2. MATERIJALI I METODE}

The experimental measurements were made on beech sawlogs $34 \mathrm{~cm}$ in diameter and $300 \mathrm{~cm}$ in length, which originate from the forests of the University Forest Enterprise of the Technical University in Zvolen. In order to calculate the production of one hollow wooden post, it was necessary to specify certain parameters such as design, which determines production technology, purpose and the place of its use. The hollow wooden posts were produced in the laboratories of the Technical University in Zvolen.

Beech wood was recommended for the purpose of this experiment, as beech is the most widespread wood species in Slovakia. Beech, however, is also a wood species with a high defect rate. In this case, the occurrence of false heartwood in the logs is not considered a defect because it does not affect the quality and exploitability of the wood for the production of the posts. Thus, such logs can be used as long as they are healthy. What is more, working lower quality raw material can give rise to unique and aesthetically interesting posts. As for their design, trapezoidal cross-section of the staves was chosen. A hollow beech-wood post was assembled from 12 staves glued together. Figure 1 shows the design and cross sectional dimensions. The hollow beech post was $2.6 \mathrm{~m}$ in length.

The technological process comprised of the following stages:

- production of special-purpose sharp timber, 


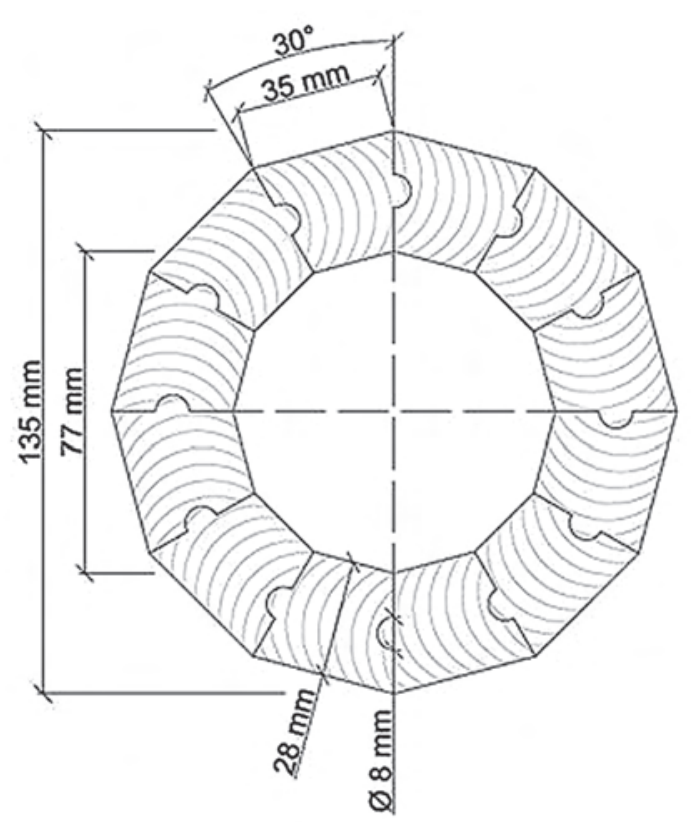

Figure 1 Design and cross sectional dimensions of a beech hollow post

Slika 1. Konstrukcija i dimenzije poprečnog presjeka šupljeg stupa od bukovine

- timber drying to the desired moisture content of $12 \pm 2 \%$ for the interior, $20 \pm 2 \%$ for the exterior,

- production of dimension timber with required allowance for trim and removal of defects,

- sorting of the dimension timber to sapwood and heartwood,

- cross-cutting to the required length with an allowance for further processing,

- planing and cutting of dimension timber to required thickness,

- CNC machining of dimension timber into a final shape,

- measurement of the dynamic modulus of elasticity (strength class according to STN EN 338),

- gluing and assembly,

- surface treatment.

With regard to their physical, mechanical, utility and aesthetic properties, hollow beech posts can be used in real constructions. It is possible to employ them in interiors as a load-bearing element of staircases, floors, balconies, etc. Considering the properties of the glue used, they can withstand even outdoor conditions. Thus, they are suitable wherever a load-bearing function is needed. If used in the exterior, the application of a special waterproof finish is necessary. Apart from their carrying function, the posts may also play an aesthetical role such as optical division of larger spaces, construction elements of furniture and interiors.

\section{RESULTS AND DISCUSSION}

\section{REZULTATI I RASPRAVA}

Pricing of the hollow post takes into consideration the production of one batch of posts, so the real costs, and thus also the market price of the product, can be calculated. For this purpose, a number of 40 hollow posts were set, which represent approximately $1 \mathrm{~m}^{3}$ of raw wood material in the form of dimension timber machined and packed into a compact stack. The moisture content of the dimension timber was $12 \pm 2 \%$.

The volume of one stave $V_{1}$ was:

$$
V_{1}=0.002002 \mathrm{~m}^{3}
$$

The volume of one product $V_{12}$ - post (12 staves):

$$
V_{12}=0.024024 \mathrm{~m}^{3}
$$

The volume of 40 posts $V_{480}$ (480 staves):

$$
V_{480}=0.96096 \mathrm{~m}^{3}
$$

The volume of unmachined staves $V_{\mathrm{US}}$ :

$$
V_{\mathrm{US}}=1.82532 \mathrm{~m}^{3}
$$

The amount of unmachined staves with the allowance for machining was estimated in accordance with STN 490231.

The production process of the post staves generated waste in the form of wooden shavings in the following proportion:

$$
V_{\text {shavings }}=V_{\mathrm{US}}-V_{480}=0.86436 \mathrm{~m}^{3},
$$

which is $2.27 \mathrm{Scm}$.

The required amount of unmachined staves was produced from sharp-edged timber of the quality class I, II and III (in accordance with STN 49 1012). Klement and Detvaj (2007) claim that theoretical yield of the staves from these quality classes represent $69.53 \%$, considering that the class ratio is $1: 1: 1$.

The consumer standard CS specifying the amount of special-purpose timber needed for the production of unmachined staves amounts to:

$$
C S=\frac{1}{0.6953}=1.438
$$

For the production of $1.83 \mathrm{~m}^{3}$ of unworked staves, the following volume of special-purpose sharpedged timber $V_{\text {SST }}$ was used:

$$
V_{\mathrm{SST}}=V_{\mathrm{US}} \cdot C S=1.83 \cdot 1.438=2.63 \mathrm{~m}^{3}
$$

The production of the staves generated waste in two forms, sawdust and small waste products. Total waste yield comprised $20 \%$ of small waste and $80 \%$ of sawdust (Klement and Detvaj, 2007).

Total waste yield:

$$
V_{\text {SST }}-V_{\text {US }}=2.63-1.83=0.8 \mathrm{~m}^{3}
$$

The amount of waste in the form of sawdust:

$$
V_{\text {sawdust }}=0.64 \mathrm{~m}^{3}=1.42 \mathrm{Scm}
$$

The amount of waste in the form of waste timber:

$$
V_{\mathrm{WT}}=0.16 \mathrm{~m}^{3}=0.42 \mathrm{Scm}
$$

It was necessary to calculate the amount of III A class of sawlogs (in accordance with STN 48 0056) required for the production of $2.63 \mathrm{~m}^{3}$ of sharp-edged timber. Klement and Detvaj (2007) also argued that, by employing a cant sawing method, the average yield of special-purpose timber, in case of a traditional and new 
method, was $45 \%$. Apart from the central timber, timber from log sides was also used, and so the total yield reached $58 \%$.

The consumption standard CS specifying the amount of sawlogs for special-purpose timber is as follows:

$$
C S=\frac{1}{0.58}=1.72
$$

The production of $2.63 \mathrm{~m}^{3}$ of sharp-edged timber required sawlogs $V$ amounting to:

$$
V=V_{\mathrm{SST}} * C S=2.63 * 1.72=4.53 \mathrm{~m}^{3}
$$

17 sawlogs with the desired dimensions have a total volume of $4.54 \mathrm{~m}^{3}$.

Klement and Detvaj (2007) stated that sawdust yield of $10 \%$ is obtained in the process of timber production, which represents $0.454 \mathrm{~m}^{3}$ or $1 \mathrm{Scm}$, while sawmill trimmings yield is $8.5 \%$, which represents $0.39 \mathrm{~m}^{3}$ of wood chips or $0.96 \mathrm{Scm}$.

The calculation of the price depends on the definition of the subject of calculation, the method of assigning the subject of calculation and the structure of costs. This is the framework for determining costs per calculation unit. The classification of costs by means of calculation structuring is based on the calculation formula, whose structure provides a basis for the recommended pricing methodology (Potkány and Merková, 2013).

The structure of the calculation formula includes the following elements:

1. direct material,

2. direct labour costs,

3. other direct costs,

1-3 Direct costs

4. manufacturing overhead,

5. administrative expenses,

6. selling expenses,

1-6 Total performance costs

7. profit.

1-7 Selling price

This cost-oriented pricing method is based on the data of direct and overhead costs. Direct costs are the costs that can be directly determined for a specific product. Overheads cannot be determined directly, and therefore they need to be added to direct costs by means of an appropriate method of calculation (Drábek and Potkány, 2008).

Direct material

Direct material includes production requirements of raw material and basic material, products, intermediate products and services. In this case, beech logs are direct material in the amount of $4.54 \mathrm{~m}^{3}-17$ logs of class III and thickness category III. The unit price stands at $€ 76.80 / \mathrm{m}^{3}$ including VAT, as specified in the price list of the University Forest Enterprise of the Technical University in Zvolen. Thus, direct material totals at $€ 348.70$.

\section{Direct labour costs}

Direct labour costs include the labour required for sawing logs, drying timber, production of rough dimension timber, fine dimension stocks, 40 posts and their treatment. The working times of the operators are determined on the basis of the normative consumption in the mechanical processing (determined from the image of the working time, the working performance). Sawing process of $4.54 \mathrm{~m}^{3}$ of sawlogs requires 2 workers who take 4 hours to perform the work. The price for drying was estimated based on a survey of companies dealing with drying of timber and logs and it amounts to $16.00 € / \mathrm{m}^{3}$ of beech timber in the form of $35 \mathrm{~mm}$ thick boards. The production of $1.83 \mathrm{~m}^{3}$ of unmachined dimension timber requires 2 workers who take approximately 2 hours to produce 480 pieces of unmachined staves. As for the production of the fine staves, one person operating a CNC machine was taken into account. The process requires 2 work shifts. The assembly of 40 posts can be performed by 2 workers for 2 work shifts. Finalisation of the hollow beech posts can be carried out by one worker for one work shift. The average hourly wage of the workforce in a sawmill operations in Slovakia is not high and amounts to $6.00 € /$ hour. + levies. In our case, the total price from the sawing stage to final product hovers at $€ 551.62$.

\section{Other direct costs}

Other direct costs include transport costs of direct material to import place. The price for transport of deciduous wood assortments by means of a hydraulicarm-equipped truck is $€ 0.22 / \mathrm{m}^{3} / \mathrm{km}$ and the price for loading and unloading is $€ 2.94 / \mathrm{m}^{3}$ as specified in the price list of the University Forest Enterprise of the Technical University in Zvolen. Furthermore, the costs include other material and tools required, such as glue, brushes, belt clamps to stabilise the posts during the curing of adhesive, and sealing rubber strips to prevent denting and bruising of wood. The production of a batch of 40 posts requires the use of 240 belt clamps, whose price is around $€ 2.00$ a piece. Polyurethanebased adhesive Xilobond T60 with an open time of 60 minutes is used for gluing. The price of the adhesive is $€ 12.00 / \mathrm{kg}$. Assuming that the application amount of glue is $140-180 \mathrm{~g} / \mathrm{m}^{2}, 7 \mathrm{~kg}$ of the adhesive must be applied with a brush, which costs $1.90 €$ per piece. The production of one batch of posts requires the use of 8 brushes. The total of other direct costs is then around $€$ 648.00 .

The direct costs, therefore, amount to $€ 1,590.50$. Manufacturing, administrative overheads and distribution expenses.

Manufacturing overheads include all costs related to the management and operation of the production process and cannot be directly determined per one calculation unit. Administrative expenses represent all primary and secondary costs related to the management and administration of a factory. Distribution expenses are comprised of selling expenses and direct selling expenses. Manufacturing, administrative and distribution overheads represent about $65 \%$ of direct material. Together, these items amount to a total of $€$ 227.00.

Thus, the total production costs are $€ 1,817.00$. Selling price

The selling price takes into account the profit of $15 \%$. The profit rate of $15 \%$ was determined from our 
own costs and is statistically justified for producers of wood-based products. This means that the selling price for 40 hollow beech posts of given structure and dimensions stands at $€ 2,090$.00. It follows that the consumer will pay $€ 53.00$ for one hollow post. Thus, the price of the glued material in the form of hollow beech posts is $€ 2,175.00 / \mathrm{m}^{3}$. The price was calculated for the product manufactured under semi-operation conditions in the development workshop.

All prices include VAT.

\section{CONCLUSION}

\section{ZAKLJUČAK}

Production of composite materials enhances efficient exploitation of wood raw material. Current advanced technologies not only allow to process less valuable wood assortments, but also wood waste materials from mechanical processing.

Load-bearing members can be produced from various materials. Solid wood is the most typical material because of its relatively low price, simplicity of processing and availability. Given its disadvantages, such as limited carrying capacity, poor fire resistance, low resistance against biological pests, a range of other materials, such as KVH- solid structural timber, glued lamellar wood, glued laminated timber (GLT), laminated veneer lumber (LVL) is used nowadays. The main advantages of these materials are dimensional accuracy of individual components, small shape and volume changes as well as dimensional variability. The advantages of hollow wooden poles are, for example, less weight compared to full wooden poles, material savings, possibility to conceal utilities, possibility of being produced in large lengths and different diameters, and good appearance from an aesthetic point of view. The disadvantage is the cavity of hollow wooden poles, which creates a chimney effect, increasing the risk of fire. Therefore, in order to increase the resistance of wooden hollow poles against fire, the chimney effect should be removed by filling the cavity of the column (e.g. with mineral wool), and treating it with flame retardant.

The price of wood raw material is relatively low compared to that of other developed countries. However, the price of engineered wood is high (Iždinský, 2008). The price of solid structural timber $(\mathrm{KVH})$ is around $€ 450.00 / \mathrm{m}^{3}$. In case of glued wood DUO, TRIO, the market price is $€ 650.00 / \mathrm{m}^{3}$. The cost of 1 $\mathrm{m}^{3}$ of laminated veneer lumber (LVL) of various materials is around $€ 1,850.00 / \mathrm{m}^{3}$. Thus, the price of wood materials with higher added value is considerably higher compared to materials from solid wood in the form of timber used for structural members. Based on calculations stated above, the calculated price was $€$ $2,175.00 / \mathrm{m}^{3}$ in case of hollow beech posts as structural glued materials with added value. This higher price is regarded reasonable considering the production technology, efficient use of wood raw material, material savings and various possibilities of use for structural or aesthetic purposes. The cost can be further reduced if the waste products are sold and thus move towards waste-free economy. A lower price can also be achieved by producing a higher number of these hollow beech posts. Employing the abovementioned measures can push the price just under $€ 2000.00 / \mathrm{m}^{3}$, which is closer to the glued materials used for building various wooden constructions.

\section{Acknowledgement - Zahvala}

This work was supported by the Slovak Research and Development Agency under the Contract No. APVV-0200-12.

\section{REFERENCES}

5. LITERATURA

1. Detvaj, J.; Argay, A.; Ruman, D., 2008: Hollow wooden post and its interaction with metal structural members. Drvna industrija, 59 (4): 181-186.

http://hrcak.srce.hr/30547.

2. Drábek, J.; Potkány, M., 2008: Ekonomika podniku. Technical University in Zvolen, 137 pp.

3. Holý, M.; Detvaj, J., 2011: History of research of hollow wooden columns at the Technical University in Zvolen. Lisove hospodarstvo, lisova, parerova i derevoobrobna promyslovist': mižvidomčyj naukovo-techničnyj zbirnyk, 37.1: 149-152.

4. Igaz, R.; Krišták, L.; Ružiak, I.; Réh, R.; Danihelová, Z., 2016: Heat transfer during pressing of 3D moulded veneer plywood composite materials. Key Engineering Materials, 688: 131-137. https://doi.org/10.4028/www.scientific.net/KEM.688.131.

5. Iždinský, J., 2008: Vel'koplošné materiály na báze dreva v stavebníctve. Stavebné materiály, č.č.12, pp. 32-35.

6. Janok, M.; Oláh, M., 1996: Cenová stratégia. Mika Conzult, Bratislava. 251 pp.

7. Klement, I.; Detvaj, J., 2007: Technológia prvostupňového spracovania dreva. Technical University in Zvolen, 325 pp.

8. Klement, I.; Huráková, T., 2016: Determining the influence of sample thickness on the high-temperature drying of beech wood (Fagus sylvatica L.). BioResources, 11 (2): 5424-5434.

https://doi.org/10.15376/biores.11.2.5424-5434.

9. Klement, I.; Huráková, T., 2015: The influence of drying characteristics and quality of spruce timber with content of reaction wood. Acta Facultatis Xylologiae Zvolen, 57 (1): 75-82.

10. Krišt’ák, L.; Igaz, R.; Brozman, D.; Réh, R.; Šiagiová, P.; Stebila, J.; Očkajová, A., 2014: Life cycle assessment of timber formwork: Case study. Advanced Materials Research, 1001: 155-161. https://doi.org/10.4028/www.scientific.net/AMR.1001.155.

11. Kúdela, J.; Čunderlík, I., 2012: Bukové drevo - štruktúra, vlastnosti, použitie. Technical University in Zvolen, pp. 152.

12. Popadić, R.; Šoškić, B.; Milić, G.; Todorović, N.; Furtula, M., 2014: Influence of the Sawing Method on Yield of Beech Logs with Red Heartwood. Drvna industrija, 65 (1): 35-42. https://doi.org/10.5552/drind.2014.1312.

13. Potkány, M.; Merková, M., 2013: Ekonomika podniku praktikum. Technical University in Zvolen, 132 pp.

14. Prekrat, S.; Župčić, I.; Ištvanić, J., 2004: Neprava srž bukovine - prednost u racionalnoj preradi i primjeni. Drvna industrija, 55 (2): 91-96. 
15. STN 48 0056: Kvalitatívne triedenie listnatej gul’atiny. 2007. (Qualitative classification of hardwood round timber. 2007.)

16. STN 49 0231: Prídavky na opracovanie reziva a prírezov reziva, drsnost' povrchu výrobkov z dreva a na báze dreva. 1993. (Allowance for machining of sawn timber and dimension timber. Surface roughness of wooden and wood-based products. 1993.)

17. STN 49 1012: Listnaté rezivo. Technické požiadavky. 1982. (Broad leaved sawn timber. Technical requirements. 1982.)

18. STN EN 338: Konštrukčné drevo. Pevnostné triedy. 2016. (Structural timber - Strength classes. 2016.)
19. *** Zelená správa, 2015: Bratislava: Ministerstvo pôdohospodárstva Slovenskej republiky, 2015, pp. 147. http:// www.mpsr.sk/sk/index.php?navID=123.

\section{Corresponding address:}

Associate professor JURAJ DETVAJ, Ph. D.

Faculty of Wood Sciences and Technology

Technical University in Zvolen

Masarykova 24

96053 Zvolen, SLOVAKIA

e-mail: detvaj@tuzvo.sk 